\title{
Research on the Deep Integration of Professional Education and Innovation and Entrepreneurship Education in Applied Universities
}

\author{
Cheng-Lei LIANG $^{1, \text { a }}$ \\ ${ }^{1}$ Cheng-Lei Liang, Dongfang College, ShanDong University of Finance and Economics, Taian, \\ China, 271000 \\ aemail:liangchenglei@163.com
}

Keywords: Applied Undergraduate, Professional education, Innovation and entrepreneurship education, Integration.

\begin{abstract}
Based on the development of the market economy and the adjustment of industrial structure, we should reform the traditional higher education to meet the urgent social needs for innovative and applied talents. The development of innovative and entrepreneurial education can effectively strengthen the training of applied talents, and has an important practical significance for promoting the development of higher education. The deep integration of innovation and entrepreneurship education and professional education is an important way to realize the transformation from common undergraduate to applied undergraduate and also the development direction of the reform of ordinary undergraduate colleges.
\end{abstract}

\section{Introduction}

For the training of applied talents, the essence of the educational concept is to follow the principle of "pragmatism" and promote the higher education to serve the society directly. With the rapid economic development in our country and the acceleration of industrialization and information technology, more and more high-level technicians in production, management and construction are required by local governments. Therefore, the applied universities bear the important task of promoting the development of the local economy.

In recent years, most of the students in universities are not clear about the job hunting intention, and the enterprise is complaining that it is difficult to recruit satisfactory talents. The formation of such a contradictory situation, in addition to the social system and personal values and other reasons, unclear location of talents training, the lack of professional awareness of students, and the inability of talent training to meet the needs of society is also a key factor. The cultivation of applied talents can help to overcome the "output problem" of college graduates.

Therefore, under the coexistence of opportunities and challenges, applied universities should be clear social service functions, and actively transform the concept of talent cultivation, and innovate the training mode of talents to meet the requirements of regional economic development and social development.

\section{The Necessity of the Organic Integration of Innovation and Entrepreneurship Education and Professional Education}

The Organic Integration of Innovation and Entrepreneurship Education and Professional Education is the Internal Demand of Higher Education

The Organic integration of innovation and entrepreneurship education and professional education is the necessary requirement for education to realize scientific development. Innovation and entrepreneurship education is aimed at excavating students' intellectual value, cultivating students' creative thinking and innovative consciousness.

The professional knowledge and professional skills of professional education are the basis for building students 'ability to innovate. Professional knowledge and professional skills have an important influence on students' thinking ability and knowledge reserve, and will determine how 
students exert their creative ability and in what fields. Only the combination of innovative and entrepreneurial education and professional education can make a scientific planning for the students' career.

\section{The Organic Integration of Innovation and Entrepreneurship Education and Professional Education is the Objective Requirement of Social Development}

In every field of social and economic development, fierce competition is leading. Under such background, the comprehensive quality, potential value and important practical ability of graduates become the same important criteria as academic qualifications.

The organic integration of innovation and entrepreneurship education and professional education can effectively cultivate talents' practical ability and innovative ability, and provide compound application talents for the society, which is the objective requirement of social development for higher education.

\section{The Insufficiency in the Integration of Innovative and Pioneering Education and Professional Education}

The training of applied talents and the innovation of entrepreneurship education are the most important problems that common colleges and universities are facing at present. On the one hand, schools should carry out application-oriented transformation and on the other hand, they should carry out education related to innovation and entrepreneurship. In essence, universities now continue the traditional mode of running schools based on disciplines and pay attention to the systematization of knowledge, and emphasizing theory and despising practice.

There are three problems in the current integration :

First, the traditional modes of running schools have a profound impact. Teachers' thinking and school management methods will continue to exist for a long period of time.

Second, too much emphasis on the cooperation between schools and enterprises neglects the cultivation process and the subjectivity of students, and thus unduly cares about the characteristics of jobs, neglects the cultivation of human comprehensive qualities.

Third, innovative education is hard to integrate with current professional education, forming an extra curriculum independent of two kinds of school running ideas, resulting in the separation of professional education from innovative education.

Properly dealing with the relationship between the two and achieving a deep integration of professional education and innovative education has become the most important issue in the transformation of general undergraduate education and is the key to achieving quality improvement in applied undergraduate education in the future. It is also necessary to adapt to the regional economic construction and social development Claim.

\section{The Way to Achieve the Organic Integration of Innovation and Entrepreneurship Education and Professional Education}

\section{Building the teaching content system of "innovation and entrepreneurship + professional education"}

The content of innovation and entrepreneurship education should be added to the course syllabus. Universities should integrate innovation and entrepreneurship education and professional knowledge and practice, create the timeliness and pertinence of the "double" education curriculum system, and set it to students' compulsory courses.

A credit transfer mechanism for innovation and entrepreneurship should be established ,such as students to participate in innovation and entrepreneurship competitions, experimental projects, research topics identified as classroom hours, can be recharged credits. 


\section{Building of Teaching Staff}

College teachers play a very important role in the integration, application oriented university in order to truly integrate into the innovation and entrepreneurship education in the professional education system, it is necessary to set up a composite teacher with the integration of "double creation" education and professional education Team.

The school should recommend the professional teachers with innovative and entrepreneurial consciousness and potential to study in the enterprise. At the same time, the school should vigorously support teachers to participate in various innovative and entrepreneurial domestic academic exchanges, so as to improve the innovation and entrepreneurial skills of teachers.

In addition, schools should open up a wide range of resources, employ relevant professionals and outstanding entrepreneurs as well as successful entrepreneurs as practical tutors.

\section{Optimizing Teaching Methods and Teaching Methods}

Applied undergraduate colleges and universities must reform their educational methods. In classroom teaching, they should adopt colorful teaching methods and methods. For example, through case analysis and role-playing, students should be encouraged to integrate their innovative spirit and entrepreneurial interest into professional learning and practice.

Teachers are mobilized to apply the latest research results, the most advanced academic development and practical experience to the classroom teaching. It is an active attempt to use the latest teaching methods, such as micro class, class and flipping class, to provide more resources for students' self-study.

\section{Building Hatching Practice Platform}

The organic integration of professional education and innovation and entrepreneurship education requires the support of various resources such as government, society and enterprises. Schools should take the initiative in social forces to promote their integration, help students improve their professional level and practical ability in practical operation, and enhance their innovative thinking and entrepreneurial ability.

First, the school and relevant departments cooperate to create the hatching practice platform, which can create the real operating field for the students in the school. For example, we should guide college students' outstanding entrepreneurial projects to locate in the industrial parks and high-tech industrial agglomeration areas built by the government, share resources in the parks, and regard industrial parks as the practice base of innovation and entrepreneurship education.

Two, schools should mobilize all kinds of resources actively, build up a demonstration base with the help of relevant national policies, and lay a strong foundation and platform for further integration.

\section{Reform the Teaching Evaluation System}

In order to achieve the close integration of professional education and innovation and entrepreneurship education, the traditional assessment methods need to be adjusted. According to the contents of professional courses, abandon rote memorization, but require students to use knowledge to analyze and solve problems; According to the characteristics of professional courses, we should actively explore diversified assessment methods, such as increasing the weight of normal homework and class performance.

Taking an additional assessment mechanism for students participating in the innovation and entrepreneurship competition and the practice of business, it not only can understand students' professional knowledge, but also fully understand their practical ability, and lay a good foundation for improving their adaptability to employment and entrepreneurship after graduation. 


\section{Reference}

[1]Jiang Jing. An analysis of the connotation and model of open school in Applied Undergraduate Colleges and universities [J]. Jiangsu high education, 2014 (1).

[2] Cen Guifang. Practical innovation of entrepreneurship education for college students in local colleges and universities [J]. Chongqing University of Science and Technology, 2013 (1).

[3]Zhang Xianyue, Chi Tingting. Innovation and entrepreneurship education in Colleges and universities to cultivate applied talents practice path[J]. Heilongjiang higher education research, 2015 (1): 147-149.

[4]Qian Jun. Research on the interaction and integration of innovation and entrepreneurship education and professional education in Colleges and universities [J]. education exploration, 2016 (11).

[5]Liu Yan. The deep integration of innovation and entrepreneurship education and professional education [J]. Chinese university teaching, 2014. 